\title{
PERAN SENI MUSIK BAGI ANAK BERKEBUTUHAN KHUSUS DI SEKOLAH DASAR
}

\author{
Abdika Alhakiki ${ }^{1}$, Desyandri ${ }^{2}$ \\ Universitas Negeri Padang, Sumatera Barat, Indonesia ${ }^{1}$, \\ abdikaalhakiki@gmail.com ${ }^{1}$, desyandri@ fip.unp.ac.id ${ }^{2}$
}

\begin{abstract}
Abstrak
Anak berkebutuhan khusus (ABK) adalah anak yang memiliki kelainan pada dirinya baik secara fisik maupun mental dan membutuhkan perlakuan khusus. Pendidikan bagi ABK diselenggarakan untuk melatih kemampuan dan keterampilan diri sebagai sarana ekplorasi diri atas keterbatasannya. Salah satu alternatif yang dapat dilaksanakan adalah dengan pendidikan seni musik. Melalui musik, siswa dapat melatih kemampuan motorik, meningkatkan konsentrasi, menumbuhkan rasa percaya diri, meningkatkan rasa syukur dan menerima keadaan, serta menumbuhkan sikap sosial. Kegiatan dalam pendidikan seni musik yang dilakukan diantaranya bernyanyi bersama teman sejawat, bermain alat musik sesuai kondisi fisik, mendengarkan lagu-lagu religi dan inspiratif.
\end{abstract}

Kata Kunci : peran, seni musik, anak berkebutuhan khusus

\begin{abstract}
The child with special needed is a child who has a disability in himself both physically and mentally and requires special treatment. Education for child with special needed is held to train their abilities and skills as a means of self-exploration for their limitations. One alternative that can be implemented is with music education. Through music, students can practice motor skills, increase concentration, foster self-confidence, increase gratitude and accept circumstances, and foster social attitudes. Activities in music art education include singing with peers, playing musical instruments according to physical conditions, listening to religious and inspirational songs.
\end{abstract}

Keywords: role, music art, the child with special needed

@Edukasi: Jurnal Ilmu Pendidikan FIP UPTT 2019

$\triangle$ Corresponding author :

Address : Rimbo Bujang, Kabupaten Tebo

ISSN 2656-8063 (Media Cetak)

Email : abdikaalhakiki@gmail.com

ISSN 2656-8071 (Media Online)

Phone : 082175227070 


\section{PENDAHULUAN}

Pendidikan merupakan sebuah ciri dari peradaban suatu bangsa. Pendidikan berhak didapatkan oleh seluruh warga Negara, sebagaimana ditegaskan dalam Undang-Undang 1945 "setiap warga Negara mempunyai kesempatan yang sama memperoleh pendidikan". Pernyataan tersebut menjelaskan bahwa kedudukan seluruh warga Negara dalam pendidikan adalah sama, tidak terkecuali anak berkebutuhan khusus.

Anak berkebutuhan khusus (ABK) adalah anak yang memiliki kelainan pada dirinya baik secara fisik maupun mental dan membutuhkan perlakuan khusus. Milyartini (2012) mengemukakan anak berkebutuhan khusus adalah anak dengan karakteristik khusus yang berbeda dengan anak pada umumnya, baik berbeda karena memiliki keterbatasan/ketidakmampuan (fisik, mental dan sosial emosi), maupun memiliki kelebihan atau keistimewaan (gifted and tallented). Namun, keterbatasan/ketidakmampuan yang dimiliki seorang ABK tidak mengartikan bahwa mereka tidak berhak mendapatkan pendidikan.

Pelayanan pendidikan untuk ABK diberikan secara khusus karena memiliki berbagai kelainan antara lain keterbelakangan mental, hambatan belajar, cacat fisik, gangguan emosi, komunikasi, pendengaran, penglihatan, dan special gifts (Mangunsong dalam Heriastuti, 2019). Salah satu upaya yang dapat dilakukan untuk melatih kemampuan dan keterampilan dalam diri $\mathrm{ABK}$ adalah melalui pendidikan seni dan budaya. Pendidikan seni dan budaya dapat dijadikan sebagai media alternatif dalam masa pendampingan melalui aktivitas kreatif ABK yang bertujuan menghasilkan sebuah karya seni yang estetis sekaligus sebagai sarana katarsis atau proyeksi anak berkebutuhan khusus dalam keinginan untuk mencoba mengungkap perasaan terdalamnya yang selama ini sulit diungkapkan (Mareza, 2017). Salah satu bentuk pendidikan seni dan budaya yang diajarkan adalah seni musik.

Oritz (dalam Heriastuti, 2019) mengemukakan bahwa manfaat yang didapat melalui musik antara lain yaitu meningkatkan kepekaan tubuh, mengaktifkan keterampilan motorik kasar, meningkatkan koordinasi, meningkatkan kepercayaan diri, dan sebagai kebahagiaan serta kesenangan anak. Manfaatmanfaat tersebut akan sangat tepat apabila diterapkan kepada ABK sejak sekolah dasar sebagai stimulus untuk melatih kemampuan dalam mengekspresikan diri secara dini.

\section{METODE PENELITIAN}

Metode yang digunakan dalam penulisan artikel ini adalah literature review atau tinjauan pustaka. Dengan melakukan evaluasi dan kajian dari penelitian-penelitian sebelumnya mengenai seni musik bagi anak berkebutuhan khusus disertai dengan teori-teori yang relevan yang selanjutnya dirangkum dan dianalisis, kemudian ditarik sebuah kesimpulan.

\section{HASIL DAN PEMBAHASAN}

Sejak awal tahun 2000 Pemerintah Republik Indonesia mengembangkan program pendidikan inklusif. Program ini merupakan kelanjutan program pendidikan terpadu yang sesungguhnya pernah diluncurkan di Indonesia pada tahun 1980an, tetapi kemudian kurang berkembang, dan baru mulai tahun 2000 dimunculkan kembali dengan mengikuti kecenderungan dunia, menggunakan konsep pendidikan inklusif untuk memperjuangkan hak-hak anak dengan hambatan belajar dan sebagai salah satu cara agar semua anak memperoleh pendidikan yang berkualitas dan layak (Desiningrum, 2016).

Dewasa ini, telah banyak pelayanan pendidikan di Indonesia yang berkembang ditujukan untuk ABK, seperti pendidikan inklusif, home schooling, dan terapi-terapi khusus (Desiningrum, 2016). Sekolah untuk ABK ada yang di sekolah umum (sekolah inklusif) bagi penyandang disabilitas ringan, dan ada yang di sekolah khusus yaitu sekolah luar biasa (SLB) dimana SD, SMP, SMA, dilaksanakan di tempat yang sama. Salah satu cara yang digunakan dalam kegiatan pembelajarannya adalah dengan seni musik. Proses yang terjadi ketika seseorang mendengarkan musik ialah gelombang listrik yang ada di otak dapat diperlambat atau dipercepat, dan pada saat yang sama kinerja sistem tubuh pun mengalami perubahan. Musik mampu mengatur hormon-hormon yang mempengaruhi stres seseorang, serta mampu meningkatkan daya ingat (Ardina, 2012).

Sebagaimana penelitian yang dilakukan oleh Turruqoyyah (2017) yang melakukan terapi musik kepada beberapa ABK dengan jenis gangguan yang berbeda, yaitu anak hiperaktif, downsyndrome, dan polio. Kegiatan terapi musik yang dilakukan yaitu terapi musik aktif dan terapi musik pasif. Perlakuan yang diberikan ialah dengan bernyanyi bersama, menirukan nada-nada, mendengarkan musik dan siswa dilatih memainkan alat musik sesuai kemampuan yang mereka miliki dengan mempertimbangkan kondisi tubuhnya. Alat 
musik yang diberikan yaitu stik sebagai bentuk latihan menggenggam, dan keyboard sebagai upaya melemaskan jari-jari hingga latihan vocal. Hasil dari penelitian tersebut menyatakan bahwa terapi musik dapat membantu ABK merelaksasi diri, meningkatkan konsentrasi dan focus, mengembangkan kemampuan fisik, mengembangkan kemampuan intelektual, mengembangkan kemampuan emosi, dan mengembangkan kemampuan sosial.

Penelitian lain yang dilakukan oleh Rifqi (2017) yang berjudul Pendidikan Seni Musik Untuk Anak Berkebutuhan Khusus di Sekolah Dasar Luar Biasa Galuh Handayani mengemukakan bahwa seni musik dapat membantu siswa dalam pengembangan motoriknya serta keseimbangan tubuh. Kegiatan pembelajarannya ada empat tahap, (1) kegiatan sebelum masuk kelas, (2) kegiatan awal, (3) kegiatan inti, dan (4) kegiatan penutup.

Pada kegiatan sebelum masuk kelas, siswa disusun seperti baris berbaris kemudian menyanyikan lagu bersama diiringi keyboard yang dimainkan oleh guru seni dilakukan 5-10 menit. Kegiatan awal, dimulai dengan berdo'a dan dilanjutkan dengan pengenalan symbol-simbol music seperti notasi, tempo dan tangga nada yang diikuti oleh seluruh siswa. Tangga nada tersebut berupa notasi angka yang sudah disusun dan diberi warna masing-masing disetiap nada contoh warna merah berarti do, warna hijau re, kuning mi, biru fa, putih sol, hitam la, orange si dengan cara ini memudahkan siswa untuk menghafal nada-nada. Kegiatan inti dilaksanakan dengan mendengarkan dan menyanyikan lagu let's see my garden dan minus one yang dimainkan oleh guru. Siswa berkelompok menyanyikan lagu tersebut di depan kelas secara bergantian. Selanjutnya, melakukan tanya jawab mengenai symbol-simbol music. Kegiatan terakhir yaitu kegiatan penutup, dilakukan dengan merangkum pembelajaran secara bersama-sama dan meminta siswa untuk mengulang atau menjelaskan kembali tentang pembelajaran yang telah dilakukan.

Kegiatan tersebut bertujuan untuk melatih pemahaman siswa mengenai bunyi, suara dan notasi angka pada musik, serta melatih kerja sama dan rasa percaya diri. Dengan kegiatan tersebut, secara tidak langsung melatih anak untuk dapat mengeksplor diri dan menguatkan mentalnya. Selain itu, di sekolah tersebut seminggu 2 kali diadakan kegiatan pada hari selasa dan hari kamis. Siswa secara individu masuk ke ruang terapi yang selanjutnya diberikan kertas dengan kegiatan mencocokkan gambar lalu siswa diarahkan melakukan permainan seperti melewati jalan setapak, ayunan, dan lompat-lompat, sesuai dengan kondisi fisiknya. Rangkaian kegiatan tersebut diiringi dengan music untuk membantu merileksasi dan memberi stimulus kepada siswa, selain itu kegiatan tersebut juga berguna sebagai upaya melatih gerak motoric pada siswa dan keaktifan otot-otot tubuhnya.

Senada dengan penelitian di atas, Fikri (2017) dalam penelitiannya yang berjudul Penguatan Nilai Agama Pada Anak Berkebutuhan Khusus (Tunanetra) Melalui Seni Musik mengemukakan bahwa lagu Islami dapat menumbuhkan ketenangan diri dan menambah ilmu agama. Kegiatan tersebut dilakukan dalam delapan kali pertemuan, dengan rangkaian kegiatan dari awal sampai akhir yaitu berwudhu, memberikan motivasi tentang bersyukur, mendengarkan lagu yang telah disiapkan, memberikan penjelasan tentang lagu yang telah didengarkan, diberikan tugas untuk menghafalkan lagu tersebut, dan memotivasi dengan kisah-kisah inspiratif.

Lagu-lagu yang didengarkan yaitu Opick rapuh, D’Masiv - Jangan Menyerah, Medina Dunia Sementara Akhirat Selamanya, dilengkapi dengan media pendukung pelatihan berupa headphone dan Al-Qur'an. Melalui nada-nada dalam musik, siswa disadarkan dengan nilai keindahan yang ada. Meskipun melalui keterbatasannya, hanya dengan pendengaran saja, siswa dapat memahami nikmat yang diberikan Tuhan padanya, sehingga ia lebih bisa menerima keadaannya dan tidak lagi merasa terpuruk. Selain itu, lagu Islami menumbuhkan sikap sosial terhadap siswa dimana muncul rasanya ingin menciptakan lagu-lagu yang indah sekaligus berdakwah untuk teman sejawatnya sebagai bentuk kepedulian terhadap sesama penyandang tunanetra. Rangkaian kegiatan pada penelitian tersebut menitikberatkan untuk tetap bersyukur atas nikmat yang telah diberikan Tuhan, dan menerima diri apapun keadaannya dengan lapang dada dan tidak menyerah.

Penelitian lain yang dilakukan oleh Fitri, Ismawan, \& Amalia (2017) tentang pembelajaran piano untuk anak autis mengemukakan bahwa belajar piano mampu meningkatkan perkembangan komunikasi dan respon anak autis terhadap hal sekitar menjadi lebih baik. Kegiatan yang dilakukan yaitu ada tiga tahap, kegiatan awal, kegiatan inti, dan kegiatan penutup. Kegiatan awal ditandai dengan menyapa siswa, guru mencairkan 
suasana, memberikan pujian dan senyuman untuk meningkatkan percaya diri siswa. Selanjutnya, kegiatan ini dilakukan dengan memperkenalkan piano, nama dan letak nada pada piano, dan menjelaskan buku panduan easy piano tentang nama nada, kunci, dan not secara perlahan. Kemudian siswa diajarkan untuk praktik bermain piano secara perlahan dengan konsentrasi. Pada kegiatan penutup, siswa diajak bernyanyi bersama dan menyimpulkan pembelajaran.

Hasil dari penelitian tersebut menyatakan bahwa piano dapat memberikan efek samping bagi penyandang autis. Dengan bermain piano, siswa dapat mengikuti ritme, melodi, dan dinamik. Selain itu, ketika siswa membaca notasi dan memainkannya, secara tidak langsung siswa belajar mengikuti perintah dan mematuhinya. Siswa yang dapat memainkan materi dengan benar, maka perilakunya juga tertata.

Penelitian tersebut menunjukkan bahwa musik mampu memberikan pengaruh terhadap ABK, baik dari segi kemampuan gerak hingga emosionalnya. Sebagaimana dikemukakan oleh Milyartini (2012), musik memiliki peran penting terhadap perkembangan anak ABK. Pertama, musik mampu meningkatkan multi kecerdasan pada $\mathrm{ABK}$. Ke dua, proses pemanfaatan musik dapat dilakukan melalui aktivitas menyimak, aktivitas memproduksi/memainkan musik dan berkarya musik yang terintegrasi dengan gerak. Ke tiga, masing-masing keterbatasan (mental, fisik, atau sosial) membutuhkan strategi pemanfaatan musik yang khas. Ke empat, aktivitas bermusik memungkinkan ABK memperoleh kepercayaan diri, harga diri dan motivasi untuk hidup lebih baik.

Sesuai dengan pendapat dan penelitian yang telah dijabarkan di atas, seni musik memiliki peran penting dalam perkembangan ABK. Pendidikan seni musik menjadi salah satu alternatif yang dapat diandalkan dunia pendidikan, terutama bagi ABK. Pendidikan seni musik untuk ABK digalakan sejak sekolah dasar, untuk melatih dan menumbuhkembangkan kemampuan diri ABK sejak dini. Pemerintah sebagai penyelenggara pendidikan hendaknya lebih turut mengutamakan pendidikan inklusif dengan penyediaan sarana dan prasarana yang memadai sehingga pendidikan yang dilaksanakan benar-benar maksimal dan berkualitas.

\section{KESIMPULAN}

Pendidikan seni musik memiliki peran penting bagi $\mathrm{ABK}$ atau penyandang disabilitas. Seni musik dapat dijadikan sebagai sarana hiburan, memberikan kesenangan kepada anak, memfasilitasi anak untuk dapat mengeksplorasi diri, melatih motorik, meningkatkan konsentrasi, menumbuhkan rasa percaya diri, meningkatkan rasa syukur dan keimanan, hingga menumbuhkan sikap sosial. Pendidikan seni musik yang dapat diajarkan kepada ABK di sekolah dasar baik sekolah inklusif maupun sekolah dasar luar biasa, diantaranya bernyanyi bersama teman sejawat, belajar dan bergerak dengan iringan music, bermain alat musik sesuai kondisi fisiknya, hingga mendengarkan lagu-lagu religi dan inspiratif dan mempraktikkan di depan kelas.

\section{DAFTAR PUSTAKA}

Ardina, M. D. (2012). Implementasi Pembelajaran Musik Untuk Mengembangkan Mental Dan Psikomotorik Anak Penderita Down Syndrom. Harmonia - Journal of Arts Research and Education, 12(2), 125-131. https://doi.org/10.15294/harmonia.v12i2.250

Desiningrum, D. R. (2016). Psiokologi Anak Berkebutuhan Khusus. Psikosain, 1-158.

Fikri, M. T. (2017). Penguatan Nilai Agama pada Anak Berkebutuhan Khusus (Tunanetra) melalui Seni Musik. II(2006), 151-164.

Fitri, A., Ismawan, \& Amalia, L. (2017). Pembelajaran Piano Untuk Anak Autisme Di Sekolah Musik Moritza. Jurnal Ilmiah Mahasiswa Program Studi Pendidikan Seni Drama, Tari Dan Musik Fakultas Keguruan Dan Ilmu Pendidikan Unsyiah, II(1), 30-38.

Heriastuti, C. A. (2019). Pembelajaran Band Pada Anak Berkebutuhan Khusus di Sekolah Luar Biasa Negeri 1 Bantul. Computers in Human Behavior, 63(May), 9-57. https://doi.org/10.1016/j.chb.2016.05.008

Mareza, L. (2017). Pendidikan Seni Budaya dan Prakarya (SBdP) Sebagai Strategi Intervensi Umum Bagi Anak Berkebutuhan Khusus. Scholaria: Jurnal Pendidikan Dan Kebudayaan, $\quad 7(1), \quad 35$ https://doi.org/10.24246/j.scholaria.2017.v7.i 1.p35-38

Milyartini, R. (2012). Peran Musik Bagi Anak Bekebutuhan Khusus (Diffabel = Different Abilities).

Rifqi, M. S. (2017). Pendidikan Seni Musik Untuk Anak Berkebutuhan Khusus di Sekolah Dasar Luar Biasa Galuh Handayani. Jurnal Pendidikan Sendratasik, 6(1). 
Turruqoyyah, I. (2017). Pelaksanaan Terapi Musik Untuk Anak Berkebutuhan Khusus (ABK) di Yayasa Pembinaan Anak Cacat (YPAC) Surakarta. ABA Journal, 102(4), 24-25. https://doi.org/10.1002/ejsp.2570 